\title{
STUDI PERILAKU INTERAKSI IKAN GUPPY JANTAN DAN BETINA (Poecilia reticulata) PADA MASA REPRODUKSI
}

\author{
Anwari Adi Nugroho*, Ahmad Muzaki, Arista Indah Anggraini, Dwi Haryanti \\ Program Studi Pendidikan Biologi \\ Fakultas Keguruan dan Ilmu Pendidikan Universitas Veteran Bangun Nusantara \\ Jl. Letjend S. Humardani No. 1, Sukoharjo, Jawa Tengah. 57521. \\ *E-mail: anwaribio@gmail.com
}

\begin{abstract}
Abstrak: Ikan guppy merupakan salah satu jenis ikan hias yang memiliki banyak jenis. Bentuk tubuh dan warna yang beragam menjadikan ikan guppy sebagai salah satu jenis ikan hias favorit untuk mengisi akuarium. Pola perawatan dan pembiakan yang mudah membuat ikan guppy banyak dibudidayakan oleh masyarakat. Penelitian ini bertujuan untuk mengetahui perilaku interaksi ikan guppy jantan dan betina (Poecilia reticulata) selama reproduksi. Penelitian ini dilakukan di rumah praktisi, pada bulan Desember 2020. Penelitian ini menggunakan penelitian deskriptif eksploratif yang dilakukan dengan mengamati perilaku ikan guppy jantan dan betina secara langsung berdasarkan pola perilaku yang terjadi. Penelitian ini menggunakan metode ad libtum sampling. Hasil penelitian menunjukkan bahwa guppy jantan memiliki tubuh yang indah dan guppy jantan selalu aktif memamerkan kecantikan tubuhnya dengan cara memiringkan tubuh ke atas sambil mengibaskan ekornya.
\end{abstract}

Kata Kunci: interaksi, Poecilia reticulata, perilaku

\section{PENDAHULUAN}

$\mathrm{I}$

kan (pisces) adalah hewan vertebrata yang hidup di dalam air seperti air tawar, air payau, dan air laut. Ikan (pisces) memiliki insang, berfungsi mengambil oksigen terlarut dari air dan sirip digunakan untuk berenang (Adrim \& Fahmi, 2010). Ikan memiliki sisik untuk menyelimuti tubuh (Cahyo, 2006). Ikan memiliki ciri-ciri umum. antara lain bertulang sejati dan bertulang rawan, mempunyai sirip tunggal atau berpasangan dan mempunyai operculum. Tubuh ikan ditutupi sisik, berlendir, serta terdapat bagian tubuh yang jelas antara kepala, badan dan ekor. Ukuran ikan bervariasi. Terdapat ikan yang berbentuk torpedo pipih, namun ada juga berbentuk tidak teratur. (Siagian, 2009).

Ikan dibagi menjadi ikan konsumsi dan ikan hias. Ikan hias adalah jenis ikan baik yang berhabitat di air tawar maupun di laut, digunakan untuk memperindah taman/ruang tamu. Jenis ikan hias yang banyak diminati antara lain, ikan arwana, ikan mas koki, ikan cupang, ikan diskus, ikan mas koi dan ikan guppy (Bachtiar, 2004). Guppy berasal dari keluarga Poecillidae. Ikan ini pertama kali ditemukan di Venezuela, Bugana dan sebagian Kepulauan Karibia. Ikan guppy memiliki karakteristik morfologi yang menarik sehingga banyak dipelihara sebagai ikan hias (Sukmara, 2007). Ikan guppy mempunyai telur-telur di dalam tubuh induknya. Ukuran guppy jantan biasanya lebih pendek dari pada guppy betina, tetapi warna guppy jantan lebih indah dan bervariasi. Ikan guppy (Poecilia reticulata) banyak diminati karena ikan guppy memiliki variasi warna yang menarik. Bentuk ekornya beragam, misalnya mirip kipas, membulat, ataupun melebar. 
Ikan guppy jantan, sirip ekor tampil sangat menarik karena lebar dan berwarna kontras dengan corak yang beragam dan warna merah yang mencolok (Arfah et al., 2005; Sukmara, 2007; Lubis \& Pujiyati, 2017). Ikan guppy (Poecilia reticulata) jantan memiliki corak warna tubuh dan sirip yang sangat cemerlang. Harga ikan guppy sangat ekonomis dibandingkan dengan ikan hias lainnya. Panjang ikan guppy di akuarium dapat mencapai $6 \mathrm{~cm}$, namun di alam kebanyakan berkisar $3 \mathrm{~cm}$. Ikan ini dapat ditemukan di berbagai tempat di daerah Jawa dan Bali (Wirjoatmodjo, 1993). Kehidupan ikan guppy dipengaruhi oleh faktor lingkungan sekitar terutama lingkungan habitatnya (Pratama et al., 2018).

Faktor suhu sangat penting untuk kehidupan dalam ekosistem perairan. Kenaikan suhu air dapat mengganggu kehidupan ikan dan hewan air lainnya (Indriyanto, 2008). Suhu merupakan salah satu faktor lingkungan yang sangat berpengaruh terhadap kehidupan makhluk hidup. Suhu dapat memberikan pengaruh baik secara langsung maupun tidak langsung. Misalnya energi cahaya mungkin diubah menjadi energi panas ketika cahaya diabsorpsi oleh suatu substansi. Suhu sering berperan bersamaan dengan cahaya dan air untuk mengontrol fungsi-fungsi organisme. Jumlah pakan yang dikonsumsi menentukan ketersediaan energi untuk pemeliharaan sel, pertumbuhan, gerak dan reproduksi (Tytler \& Calow., 1985). Menurut Fange \& Grov hubungan antara pakan dan ikan dipengaruhi oleh beberapa faktor, diantaranya nafsu makan. Nafsu makan akan bertambah ketika suhu meningkat, namun pada kisaran di atas suhu optimumnya nafsu makan akan menurun kembali (Zonneveld \& Boon, 1991).

Jangka waktu masa kehamilan ikan guppy (Poecilia reticulata) relatif pendek. Hanya berkisar antara 21-30 hari (rata-rata 28 hari) bergantung pada suhu airnya. Suhu air yang paling cocok untuk berbiak adalah sekitar $27^{\circ} \mathrm{C}\left(72^{\circ} \mathrm{F}\right)$. Pada masa reproduksi, ikan guppy memiliki perilaku yang khas terutama interaksi antara jantan dan betina. Perilaku yang khas tersebut perlu diketahui dan diteliti lebih lanjut. Penelitian ikan guppy tentang perilakunya pada masa reproduksi masih sangat sedikit. Beberapa penelitian yang telah dilakukan tentang ikan guppy antara lain maskulinisasi ikan guppy (Matondang et al., 2018; Malik et al., 2019), perilaku makan ikan guppy (Lucon-Xiccato \& Bertolucci, 2019), perilaku kawin ikan guppy (Zhang et al., 2019) dan pengaruh lingkungan habitat terhadap warna ikan (Pratama et al., 2018). Berdasarkan uraian latar belakang maka perlu dilakukan penelitian tentang perilaku interaksi ikan guppy (Poecilia reticulata) jantan dan betina pada masa reproduksi.

\section{METODE PENELITIAN}

Penelitian dilaksanakan pada bulan Desember tahun 2020. Jenis penelitian ini adalah penelitian deskriptif eksploratif yaitu mengamati perilaku ikan guppy jantan dan betina secara langsung berdasarkan perilaku interaksi yang terjadi pada masa reproduksi. Penelitian menggunakan metode ad libtum sampling yaitu penelitian dengan cara mengamati seluruh aktivitas yang terlihat menggunakan batasan aktivitas berdasarkan fakta lapangan (Altmann, 1974).

Kegiatan penelitian perilaku interaksi ikan guppy jantan dan betina pada masa reproduksi ini menggunakan beberapa alat sebagai pendukung penelitian, diantaranya seperti akuarium, termometer, alat dokumentasi dan jaring. Sedangkan bahan yang digunakan yaitu ikan guppy jantan sebanyak 3 ekor dan ikan guppy betina sebanyak 3 ekor. Ikan guppy dalam penelitian ini adalah ikan guppy dengan umur sekitar 4-5 bulan, sehingga sudah masuk pada fase dewasa dan siap kawin. 
Prosedur penelitian perilaku interaksi ikan guppy jantan dan betina pada masa reproduksi dapat diamati pada Gambar 1.

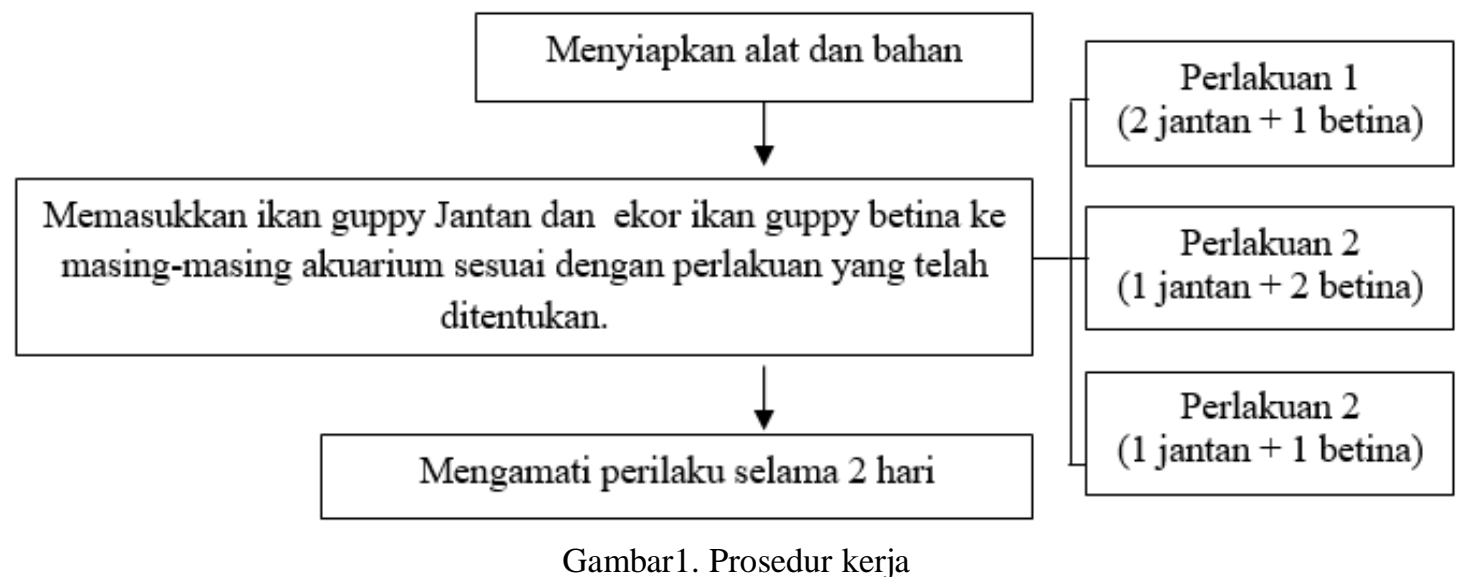

Secara detail, Gambar 1 dapat dijelaskan sebagai berikut: a) Menyiapkan alat dan bahan dalam penelitian; b) Meletakkan ikan guppy jantan dan ikan guppy betina ke masing-masing akuarium sesuai dengan perlakuan 1,2 dan 3. Perlakuan pada ikan guppy jantan dan ikan gupy betina dalam penelitian ini antara lain, perlakuan 1 (2 ikan guppy jantan dan 1 ikan guppy betina); perlakuan 2 (1 Ikan guppy jantan dan 2 Ikan guppy betina); serta perlakuan 3 (1 ikan guppy jantan dan 1 ikan guppy betina); c) Mengamati perilaku interaksi ikan guppy jantan dan ikan guppy betina selama kurang lebih 2 hari pada waktu pagi dan sore hari. Data perilaku diambil dengan cara observasi langsung menggunakan lembar observasi, catatan pengamatan, dan alat dokumentasi. Data dianalisis secara deskriptif yaitu mendeskripsikan perilaku ikan guppy jantan dan betina yang muncul selama pengamatan.

\section{HASIL DAN PEMBAHASAN}

Ikan guppy (Poecilia reticulata) memiliki ciri ekor yang lebar dengan bentuk setengah lingkaran.Ciri unik pada ikan guppy ini memiliki warna yang beranekaragam. Ikan guppy pada masa reproduksi memiliki perilaku yang khas apabila digabungkan antara jantan dan betina. Interaksi terjadi antara jantan dan betina sebagai bentuk respon pada saat akan melakukan perkawinan. Penelitian ini mengamati perilaku interaksi ikan guppy jantan dan betina pada masa reproduksi dengan cara menempatkan jantan dan betina pada satu wadah dan diamati selama 2 hari.

Pengamatan pertama dilakukan dengan mengamati interaksi perilaku 2 ekor ikan guppy jantan dengan 1 ekor ikan guppy betina dalam satu wadah akuarium. Untuk mempermudah dalam penetuan atraktan maka dilakukan dengan pemberian sampel nama. Sampel A untuk ikan guppy jantan 1, sampel B untuk ikan guppy jantan 2, dan sampel C untuk ikan guppy betina. Hasil pengamatan dapat dilihat dalam Tabel 1. 
Tabel 1. Interaksi perilaku dua ikan guppy jantan dan satu betina

\begin{tabular}{lccccc}
\hline Detik & P1 & P2 & P3 & P4 & P5 \\
\hline $1-30$ & A,B & C & - & - & - \\
$31-60$ & A & C & - & - & - \\
$61-90$ & A & C & - & - & A,B \\
$91-120$ & A,B & C & - & - & A,B \\
$121-150$ & - & - & - & - & A,B \\
$151-180$ & A,B & C & - & - & A,B \\
$181-210$ & - & - & - & - & A,B \\
$211-240$ & A & C & - & - & A,B \\
$241-270$ & A,B & C & - & - & A,B \\
$271-300$ & A,B & C & - & - & A=7, B=7 \\
\hline Jumlah & A=8, B=5 & C: 8 & - & - & -
\end{tabular}

Keterangan: $\mathrm{A}=$ jantan $1 ; \mathrm{B}=$ jantan $2 ; \mathrm{C}=$ betina; $\mathrm{P} 1=$ mendekati lawan jenis; $\mathrm{P} 2=$ menghindar, $\mathrm{P} 3=$ memiringkan badan; P4 = diam di dasar akuarium; dan P5 = berinteraksi dengan sesama jenis

Berdasarkan hasil pengamatan pada Tabel 1, didapatkan hasil bahwa pada perilaku 1 atau P1 berupa mendekati lawan jenis, didapatkan hasil berupa ikan guppy jantan A mendekati ikan guppy betina sebanyak 8 kali, sedangkan ikan guppy jantan B mendekati ikan betina sebanyak 5 kali. Namun di lain sisi pada perilaku 2 atau P2 berupa menghindar ditemukan hasil bahwa ikan guppy betina menghindar terhadap ikan guppy jantan sebanyak 8 kali yang mana merupakan interaksi yang sama yang dilakukan masingmasing ikan guppy jantan terhadap ikan guppy betina. Contoh interaksi ikan guppy 2 jantan dan betina dapat dilihat pada Gambar 2.

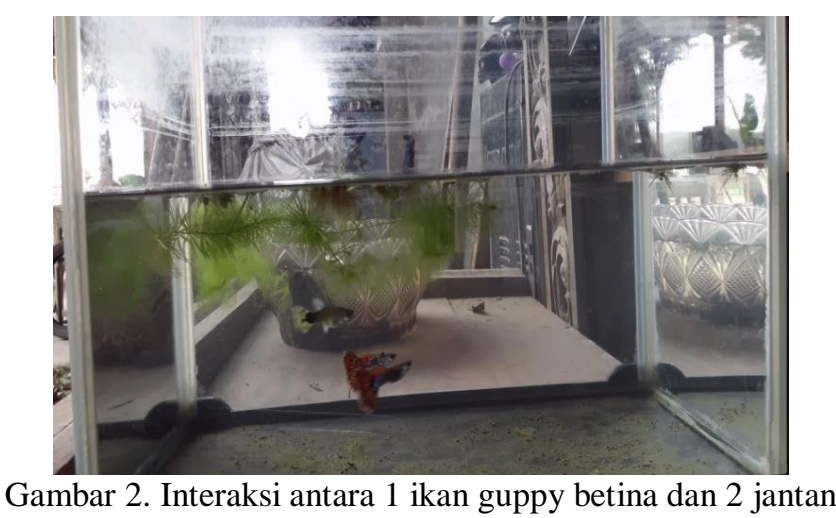

Pada saat pengamatan juga ditemukan tingkah laku yang menunjukkan pola interaksi ikan guppy terhadap sesama jenisnya yang direpresentasikan pada perilaku 5 atau P5, dimana ditemukan interaksi ikan guppy jantan dengan sesamanya sebanyak 7 kali. Dari perlakuan 1 ini dimana menempatkan 2 ekor ikan guppy jantan dan 1 ekor ikan guppy betina ditemukan fakta bahwa, 2 ekor ikan guppy jantan saling bergantian berebut untuk mendapatkan perhatian ikan guppy betina, kedua ikan guppy jantan juga saling berinteraksi dengan saling menghalangi sesamanya agar tidak mendekati ikan guppy betina. Cara ikan guppy jantan dalam menarik pasangannya adalah dengan menarikan tubuhnya dan mengibaskan ekornya. Penempatan 2 ekor ikan guppy jantan dan 1 ekor ikan guppy betina, ternyata tidak menunjukan pola interaksi yang baik, hal tersebut bisa diamati dimana ikan guppy betina selalu menghindar apabila didekati dari masing-masing ikan guppy jantan.

Pengamatan kedua dilakukan dengan mengamati interaksi perilaku 1 ekor ikan guppy jantan dengan 2 ekor ikan guppy betina. Untuk mempermudah dalam penentuan 
maka dilakukan dengan pemberian sampel nama. Sampel A untuk jantan, sampel B untuk betina 1, dan sampel $\mathrm{C}$ untuk betina 2 . Hasil pengamatan dapat tercermin dalam Tabel 2.

Tabel 2. Interaksi perilaku satu ikan guppy jantan dan dua betina

\begin{tabular}{lccccc}
\hline Detik & P1 & P2 & P3 & P4 & P5 \\
\hline $1-30$ & A & - & A & - & B,C \\
$31-60$ & A,B & - & A & - & - \\
$61-90$ & A & - & A & - & - \\
$91-120$ & A & - & A & - & - \\
$121-150$ & A & - & A & - & - \\
$151-180$ & - & - & - & A & - \\
$181-210$ & A & - & A & - & B,C \\
$211-240$ & - & - & - & A & B,C \\
$241-270$ & - & - & - & A & B,C \\
$271-300$ & A & - & A & - & - \\
\hline Jumlah & A=7, B=1 & - & A $=7$ & A=3 & B=4, C=4 \\
\hline
\end{tabular}

Keterangan: $\mathrm{A}=$ jantan $1 ; \mathrm{B}=$ jantan $2 ; \mathrm{C}=$ betina; $\mathrm{P} 1=$ mendekati lawan jenis; $\mathrm{P} 2=$ menghindar, $\mathrm{P} 3=$ memiringkan badan; $\mathrm{P} 4=$ diam di dasar akuarium; dan P5 = berinteraksi dengan sesama jenis

Berdasarkan hasil pengamatan pada Tabel 2, didapatkan hasil bahwa pada tingkah laku 1 atau P1 berupa mendekati lawan jenis, didapatkan hasil berupa ikan guppy jantan melakukan pendekatan terhadap ikan guppy betina sebanyak 7 kali serta ikan guppy betina B satu kali. Berkaitan dengan hal tersebut pada perilaku 3 atau P3 berupa memiringkan badan ternyata tingkah laku tersebut hanya dilakukan oleh ikan guppy jantan dengan representasi sebanyak 7 kali, selain itu perilaku diam di dasar akuarium ternyata juga hanya dilakukan oleh ikan guppy jantan dengan nilai kecil yaitu sebanyak 3 kali. Selain itu pada saat pengamatan ditemukan perilaku yang menunjukkan pola interaksi ikan guppy terhadap sesama jenisnya yang direpresentasikan pada perilaku 5 atau P5, dimana ditemukan interaksi ikan guppy betina dengan sesamanya sebanyak 4 kali. Contoh interaksi ikan guppy jantan dan 2 betina dapat dilihat pada Gambar 3 .

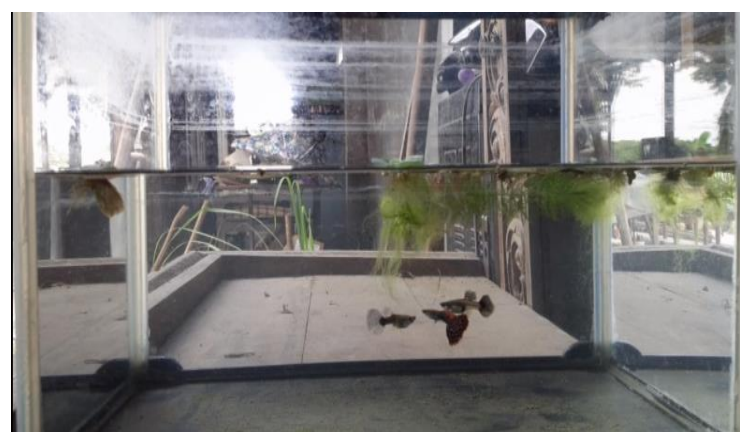

Gambar 3. Interaksi antara 1 ekor ikan guppy jantan dan 2 betina

Berdasarkan perlakuan 2 dengan menempatkan 1 ekor ikan guppy jantan dan 2 ekor ikan guppy betina ditemukan fakta bahwa, ikan guppy jantan secara aktif sering mendekati ikan guppy betina dengan menunjukan keindahan tubuhnya, hal tersebut juga didukung dengan pola memiringkan badan tegak miring yang hanya ditemukan pada ikan guppy jantan. Hal tersebut merupakan ciri umum ikan guppy jantan dalam mendekati lawan jenisnya. Namun di beberapa kondisi tertentu ditemukan juga bahwa ikan guppy jantan melakukan istirahat di dasar akuarium dengan durasi waktu 30 detik sampai satu menit. Kedua ikan guppy betina juga terkadang saling berinteraksi dengan berdekatan dan saling tatap. 
Pengamatan ketiga dilakukan dengan mengamati interaksi perilaku 1 ekor ikan guppy jantan dengan 1 ekor ikan guppy betina. Untuk mempermudah dalam penetuan maka dilakukan dengan pemberian sampel nama. Sampel A untuk ikan guppy janta dan sampel B untuk ikan guppy betina. Hasil pengamatan tercermin dalam Tabel 3.

Tabel 3. Interaksi perilaku satu ikan guppy jantan dan satu betina

\begin{tabular}{lcccc}
\hline Detik & P1 & P2 & P3 & P4 \\
\hline $1-30$ & A & - & A & - \\
$31-60$ & - & - & A & - \\
$61-90$ & A & - & A & - \\
$91-120$ & - & - & A & - \\
$121-150$ & - & - & A & - \\
$151-180$ & - & - & A & - \\
$181-210$ & - & - & A & - \\
$211-240$ & - & - & A & - \\
$271-270$ & A & - & A & - \\
\hline Jumlah & A & - & A & A=10 \\
\hline
\end{tabular}

Keterangan: $\mathrm{A}=$ jantan; $\mathrm{B}=$ betina $1 ; \mathrm{P} 1=$ mendekati lawan jenis; $\mathrm{P} 2$ = menghindar; $\mathrm{P} 3$ = memiringkan badan; dan $\mathrm{P} 4$ = diam didasar akuarium

Berdasarkan hasil pengamatan pada Tabel 3, didapatkan hasil bahwa pada perilaku 1 atau P1 berupa mendekati lawan jenis, didapatkan hasil berupa ikan guppy jantan melakukan pendekatan terhadap ikan guppy betina sebanyak 4 kali. Selain itu pada pengamatan perlakuan 3 ini ditemukan perilaku memiringkan badan yang dilakukan oleh ikan guppy jantan yaitu sebanyak 1 kali atau hampir setiap waktu. Dari perlakuan 3 ini dimana menempatkan 1 ekor ikan guppy jantan dan 1 ekor ikan guppy betina ditemukan fakta bahwa, ikan guppy jantan secara aktif memamerkan keindahan tubuhnya sepanjang waktu dengan cara memiringkan tubuhnya secara tegak miring sambil mengibaskan ekornya. Tingkah laku ini dilakukan ikan guppy jantan terhadap ikan guppy betina pada posisi yang berdekatan maupun berjauhan. Contoh interaksi ikan guppy jantan dan betina pada perlakukan 3 dapat dilihat pada Gambar 4.

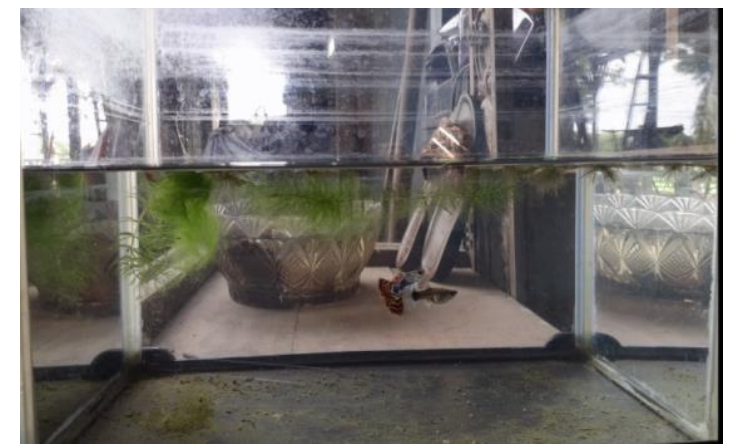

Gambar 4. Interaksi antara 1 ekor ikan guppy jantan dengan 1 betina

Hasil perlakukan 1, 2 dan 3 secara keseluruhan menunjukkan bahwa terdapat interaksi antara ikan guppy jantan dan betina pada saat ditempatkan pada akuarium yang sama. Ikan jantan lebih aktif dalam berinteraksi dengan betina seperti mendekati betina dan memiringkan badan. Sedangkan ikan betina cenderung kurang aktif karena hanya menanggapi perilaku dari jantan. Penelitian tentang perilaku kawin ikan guppy menunjukkan bahwa terganggunya perilaku kawin dan penurunan daya tarik ikan betina pada ikan jantan dapat mengakibatkan kegagalan reproduksi (Zhang et al., 2019). Hasil 
tersebut menunjukkan bahwa ikan guppy seperti kebanyakan ikan hias kecil lainnya memiliki perilaku khas ketika ikan jantan dan betina disatukan dalam wadah seperti ikan cupang (Nugroho et al., 2020) dan ikan pelangi (Herjayanto, 2016).

\section{KESIMPULAN}

Berdasarkan penelitian perilaku interaksi ikan guppy jantan dan betina pada masa kawin, maka dapat disimpulkan bahwa ikan guppy jantan memiliki perilaku yang lebih aktif dan agresif daripada ikan guppy betina. Sikap tersebut ditunjukkan ketika ikan guppy jantan dan ikan guppy betina berada dalam satu wadah yang sama. Ikan guppy jantan secara aktif memamerkan keindahan tubuhnya dengan cara memiringkan tubuhnya secara tegak miring sambil mengibaskan ekornya. Perilaku tersebut terlihat dari perilaku ikan guppy jantan saat berada di dalam perlakuan 1,2 dan 3. Sedangkan ikan guppy betina cenderung kurang aktif dan hanya menanggapi keaktifan dari ikan guppy jantan. Interaksi ikan jantan dan betina tersebut sebagai bentuk perilaku ikan guppy dalam masa reproduksi.

\section{DAFTAR PUSTAKA}

Adrim, M., \& Fahmi. (2010). Panduan Penelitian Untuk Ikan Laut. Jakarta: Pusat Penelitian OseanografiLIPI.

Altmann, J. (1974). Observational study of behavior: sampling methods. Behaviour, 49(3/4), 213-221.

Arfah, H. I. A. K. Kadriah., \& O. Carman. (2005). Efek manipulasi hormon 17 $\alpha$-metiltestosteron pada berbagai variasi temperatur air terhadap rasio kelamin ikan gapi (Poecilia reticulata Peters). Jurnal Akuakultur Indonesia, 4(1), 37-40.

Bachtiar, Y. (2004). Budidaya Ikan Hias Air Tawar Untuk Ekspor. Jakarta: Agro Media Pustaka.

Cahyo. (2006). Panduan Penelitian Untuk Ikan Tawar. Jakarta: Pusat Penelitian Oseanografi-LIPI.

Herjayanto, M. (2016). Tingkah laku memijah, potensi reproduksi ikan betina, dan optimasi teknik pemijahan ikan pelangi (Iriatherina werneri Meinken, 1974). Jurnal Iktiologi Indonesia, 16(2), $171-183$.

Indriyanto. (2008). Ekologi Hutan Ed ke-2. Jakarta: PT. Bumi Aksara.

Lubis, M. Z., \& Pujiyati, S. (2017). Pengaruh aklimatisasi kadar garam terhadap nilai kematian dan tingkah laku ikan guppy (Poecilia reticulata) sebagai pengganti umpan ikan cakalang (Katsuwonus pelamis). Jurnal Teknologi Perikanan dan Kelautan, 4(2), 123-129. https://doi.org/10.24319/ jtpk.4.123-129.

Lucon-Xiccato, T., \& Bertolucci, C. (2019). Guppies show rapid and lasting inhibition of foraging behaviour. Behavioural Processes, 164(March), 91-99. https://doi.org/10.1016/j.beproc. 2019.04.011.

Malik, T., Syaifudin, M., \& Amin, M. (2019). Maskulinisasi ikan guppy (Poecilia reticulata) melalui penggunaan air kelapa (Cocos nucifera) dengan konsentrasi berbeda. Jurnal Akuakultur Rawa Indonesia, 7(1), 13-24. https://doi.org/10.36706/jari.v7i1.9017.

Matondang, A. H., Basuki, F., \& Nugroho, R. A. (2018). Pengaruh lama perendaman induk betina dalam ekstrak purwoceng (Pimpinela alpina) terhadap maskulinisasi ikan guppy (Poecilia reticulata). Journal of Aquaculture Management and Technology, 7(1), 10-17.

Nugroho, A. A., Latifa, U. N., Rahayu, N. Y., \& Setyawan, A. F. (2020). Interaksi tingkah laku ikan cupang jantan dan betina (Betta splendes) pada masa kawin. Science Education and Application Journal, 2(1), 27-34. https://doi.org/10.30736/seaj.v2i1.186.

Pratama, D.R., Wijayanti, H., \& Yulianto, H. (2018). Pengaruh warna wadah pemeliharaan terhadap peningkatan intensitas warna ikan guppy (Poecilia reticulata). E-Jurnal Rekayasa dan Teknologi Budidaya Perairan, 7(1), 775-782. https://doi.org/10.23960/jrtbp.v7i1.p775-782.

Siagian, C. (2009). Keanekaragaman dan Kelimpahan Ikan Serta Keterkaitannya dengan Kualitas Perairan di Danau Toba. [Tesis]. Medan: Universitas Sumatera Utara Medan.

Sukmara. (2007). Peningkatan intensitas ikan guppy (Poecilia reticulata). E-Jurnal Rekayasa dan Teknologi Budidaya Perairan, 7(1).

Tytler, P., \& Calow., P. (1985). Fish Energetics: New Perspetives. Sydney, Australia: Croom Helm Ltd. Wirjoatmodjo. (1993). Ikan Air Tawar Indonesia Bagian Barat dan Sulawesi. Jakarta: Periplus Edition (HK) Ltd. dan Proyek EMDI KMNKLH. 
Zhang, J. L., Zhang, C. N., Li, E. C., Jin, M. M., Huang, M. X., Cui, W., ... Shi, Y. J. (2019). Triphenyltin exposure affects mating behaviors and attractiveness to females during mating in male guppies (Poecilia reticulata). Ecotoxicology and Environmental Safety, 169(August 2018), $76-84$. https://doi.org/10.1016/j.ecoenv.2018.11.011

Zonneveld, N., A, H. E., \& Boon, J. H. (1991). Prinsip-Prinsip Budidaya Ikan. Jakarta: Gramedia Pustaka Utama. 